\title{
Obtaining and Characterization of a Polyurethane Carrier Used for Eugenol as a Possible Remedy in Oral Therapies
}

\author{
ZORAN POPA ${ }^{1 \#, ~ L A U R A ~ C R I S T I N A ~ R U S U 2 \#, ~ R A Z V A N ~ S U S A N ~}{ }^{1}$, IULIA PINZARU ${ }^{3}$, ELENA ARDELEAN ${ }^{1}$, FLORIN BORCAN ${ }^{3}$, \\ MIRELA VOICU ${ }^{3}$, IOANA TUTA SAS ${ }^{3}$, RAMONA AMINA POPOVICI ${ }^{2 *}$, VOICHITA LAZUREANU ${ }^{1}$ \\ ${ }^{1}$ Victor Babes University of Medicine and Pharmacy Timisoara, Faculty of Medicine, 2 Eftimie Murgu Sq., 300041, Timisoara, \\ Romania \\ ${ }^{2}$ Victor Babes University of Medicine and Pharmacy Timisoara, Faculty of Dentistry, 2 Eftimie Murgu Sq., 300041, Timisoara, \\ Romania \\ ${ }^{3}$ Victor Babes University of Medicine and Pharmacy Timisoara, Faculty of Pharmacy, 2 Eftimie Murgu Sq., 300041, Timisoara, \\ Romania
}

\begin{abstract}
The cloves are antiseptic, antiparasitic, antibacterial, antifungal, antiviral, anesthetic, analgesic, antiinflammatory, tonic, carminative, anti-ulcer, antithrombotic, antioxidant and anti-cancerous. They contain eugenol, tannins and flavonoids that also help to strengthen the vein wall. This paper presents the obtaining and the characterization of a polyurethane drug delivery system which can be used for the transmembrane transport of eugenol in oral therapies. The products were analyzed by $\mathrm{pH}$ and solubility measurements, thermal decomposition and zetasizer tests and they were applied on mice skin to evaluate their harmfulness. The results suggest that were obtained neutral pH structures with low solubility and a good thermal stability, with sizes between 241 and $289 \mathrm{~nm}$ and no toxicity effect was found in the case of studied samples.
\end{abstract}

Keywords:drug carrier, DSC, eugenol, polyurethane, zetasizer

Medicinal benefits of many herbs and trees are unquestionable. The modern investigation techniques allow the discovery of active principle from every natural extract [1]. Healers from China and India have been using clove buds since ancient times as part of their treatment. The cloves were listed in Hildegard's Medicine, a compilation of German medical papers signed by reputed Benedictine botanist Hildegard de Bingen (1098-1179) [2] . Eugenol, the main element in the cloves composition, is used in the dental industry to numb the gums. Courmontet al. have demonstrated that a solution of $0.05 \%$ of eugenol from the clove oil is enough to kill the tuberculosis bacillus [3].<smiles>C=CCc1ccc(O)c(OC)c1</smiles>

Fig. 1. Chemical structure of eugenol

Polyurethane is an inert, biodegradable and biocompatible material. Simple changes of precursors and/ or their ratios lead to drug carrierstructures with adjustable sizes and morphologies [4, 5]. Polyurethanes were found by Prof. Otto Bayer 80 years ago in his laboratory from Interessen-GemeinschaftFarbenindustrie AG Leverkusen; Pangman introduced this material between the medical applications twenty years laterwhen he used it as composite breast prostheses, respectivelyMandrino and Salvatore used it for in situ bone fixation [6].

The main disadvantage of eugenol therapy is represented by its limited time action. The aim of this study was to obtain polyurethane structures withentrapped eugenol in order to prolong its action in an oral therapy.

\section{Experimental part}

\section{The reagents}

Hexamethylene-diisocyanate (HMDI),polyethylene glycol, $M H \approx 200$ (PEG), the solvent (acetone) and surfactant (Tween ${ }^{\circledR 20}$ ) were obtained from Merck (Germany); ethylene glycol (EG) was purchased from Lach-Ner (Czech
Rep.), and eugenol from Sigma-Aldrich.The reagents were used without any previous purification.

\section{The obtaining of samples}

The polyurethane structures were obtained following a protocolwhich was already described in scientific literature in our previous papers [7-17]:

The $1^{\text {st }}$ step -The preparations of the two phases

The aqueous orhydroxy-phase comprises a mixture of ether and/or ester polyols (e.g. polyethylene-glycol, polyepsilon-caprolactone) as the main component, diols or diamines with low molecular weight (e.g. ethylene glycol, 1,4-butanediol, 1,6-hexanediol or ethylene diamine) used as chain extendersand a surfactant (e.g. Tween or Span) which are dissolved in distilled water, heated at $35^{\circ} \mathrm{C}$ and homogenized at $300 \mathrm{rpm}$ for at least $20 \mathrm{~min}$.

Separately, the organic-phase comprising one or two aliphatic di-isocyanates (e.g. isophorone-diisocyanate, hexamethylenediisocyanate, lysine-diisocyanate) dissolved in acetone, heated at $35^{\circ} \mathrm{C}$ and homogenized at $300 \mathrm{rpm}$ for at least $20 \mathrm{~min}$.

The biological active substance is introduced in a ratio of $5-15 \%$ in one of the two phases depending on the reactivity of its functional groups and/or its solubility in water and acetone. Eugenol was introduced into the aqueous orhydroxyl-phase.

\section{The $2^{\text {nd }}$ step -The mixing of the two phases}

The organic-phase is rapidly injected into the hydroxyphase, heated at $40^{\circ} \mathrm{C}$ and magnetically stirred at 350 $\mathrm{rpm}$. This is the moment when the polyurethane structures begin to form and the obtained solution begins to turbid. The stirring will continue, with heating for approx. $4 \mathrm{~h}$; the finishing of the polyurethane structures'walls (maturing of the finished product) is a lasting process because no catalyst was used at all.In the polyurethane industry, the syntheses involves the use of a catalyst such as tertiary amine compounds (e.g. 1,4-diazabicyclo [2.2.2] octane) or an organometallic derivative of tin. 
The $3^{\text {rd }}$ step -The purification of obtained products

A ratio between the hydroxyl- and organic-phase of 1.2: 1 , with an excess of alcohol compounds, was used in relation to the isocyanate stoichiometric requirement in order to prevent the formation of secondary products. However, it is possible to have different amines through final products, resulting from the reaction of isocyanates with water. The synthesized products were washed at least 3 times with a 1:3 (v/v) water-acetone mixture in order to remove these amines or some unreacted precursors.

\section{The $4^{\text {th }}$ step -The storage of products}

The obtained emulsions were layered in Petri dishes and dried at room temperature for approx. 10 days until it is noticed that the mass of the Petri dish is no longer changing. The resulting powder is stored in Eppendorf tubes at room temperature for further evaluation.

Two different samples (EU 0 and EU 1) were synthesized using the procedure previously described; theprecursors used for the synthesis of every sample are presented in table 1.

\section{The determination of $\mathrm{pH}$ and solubility}

The samples' solubility in different solvents (distilled water, ethanol, acetone, DMSO) was evaluated at $25 \pm 1^{\circ} \mathrm{C}$, using a procedure described in ASTM D 3132-84. The $\mathrm{pH}$ values of the diluted aqueous solutions at the same concentration $(0.8 \mathrm{mg} / \mathrm{mL})$ were evaluated in triplicate using a portable pH Meter Checker ${ }^{\circledR}$ (Hanna instruments, USA) at the same temperature $\left(25 \pm 1^{\circ} \mathrm{C}\right)$. The instrument was previously calibrated using four different buffer solutions ( $p \mathrm{H}=3,5,7$ and 10$)$.

\section{Thermal decomposition and zetasizer characterization}

Differential scanning calorimetry (DSC) was the technique used to characterize the thermal behavior of samples; the analysis was carried out with a Mettler-Toledo DSC1 instrument (Mettler-Toledo, Switzerland). The samples were placed in aluminum crucibles with pierced caps and were heated between -10 and $290^{\circ} \mathrm{C}$ in an inert atmosphere with a heating speed equal with 5 degree/ min. A reference material (empty aluminum crucible with pierced cap) simultaneously undergoes the same routine.

The surface charge / stability against agglomeration and the size of polyurethane structures were tested with a CordouanZetasizer instrument (Cordouan Technol., France); the following Vasco Particle Size Analyzer parameters were chosen: temperature $\left(25^{\circ} \mathrm{C}\right)$, time interval $(40 \pm 5 \mu \mathrm{s})$, and number of channels $(400 \pm 20)$, laser power ( $85 \pm 5 \%)$, acquisition mode (continuous), and analysis mode (Pade-Laplace). The following Wallis Zetapotential Analyzer parameters were chosen: plastic cuvette at a temperature equal with $25^{\circ} \mathrm{C}$, laser power (90\%), applied field (automatic), resolution (medium, 0.8 $\mathrm{Hz}), 5$ measures/sequence, and Henry function (Smoluchowski).
Yield of encapsulation

The entrapment efficiency was calculated based on a method described by C.P. Doraetal. [18]: the free, entrapped drug can be measured by Beer-Lambertlaw and itis related to the quantity of drug added to the synthesis.

The formula is:

$$
\text { Entrapment efficiency }(\mathrm{EE})=\left(1-\frac{\text { Quantity of free drug }}{\text { Quantity of drug added }}\right) \cdot 100
$$

Animals

C57 female mice ( 8 weeks old at the beginning of tests) were acquired from Charles River (Budapest, Hungary). The work protocol was analyzed and approved by our ethics committeeand it followed the National Institute of Animal Health rules: animals were maintained inside the university Biobase, in standard conditions: $12 \mathrm{~h}$ light-dark cycle, food and water ad libidum, temperature $24 \pm 1^{\circ} \mathrm{C}$, humidity above $55 \%$.

Polyurethane structures without and with eugenol (EU 0 and EU 1) and blank solution (solvent without any active compoünd) were applied on mice skin for 21 days ( $50 \mu \mathrm{L}$ solution / application). 12 mice were used in this experiment: group blank (4 mice treated with solvent), group EU 0 (4 mice, treated with empty polyurethanes structures)and group EU 1 (4 mice, treated with polyurethane structures with eugenol). The mice were shaved in the first, the $6^{\text {th }}$ and the $15^{\text {th }}$ day and the applications and measurements were done every three days.

The determinations were performed within $30 \mathrm{~min}$ after each application. All measurements on the mice skin were carried out with a Multiprobe Adapter System (MPA5) from Courage-Khazaka, Germany: the measurements of transepidermalwaterloss (TEWL) were carried out with a Tewameter ${ }^{\circledR}$ TM 300 probe, the levels of melanin and erythemawere tested with a Mexameter ${ }^{\circledR} \mathrm{MX} 18$ probe and the moisture of corneous layer with a Corneometer ${ }^{\circledR} \mathrm{CM}$ 825 probe.

\section{Statistics}

All statistical analyses were performed using a trial version of IBM SPSS.Numerical data were presented as mean \pm standard errors.Student $t$ test was used to determine the statistical difference between various experimental groups. Statistical significance was considered at a $p$-value less than $0.05 ; *, * *$ and $* * *$ indicate $p<0.05, p<0.01$ and $<0.001$.

\section{Results and discussions}

Eugenol is a phenylpropanoid compound, liquid at room temperature $\left(\mathrm{m} . \mathrm{p} .=-7.5^{\circ} \mathrm{C}\right)$ with a good solubility in organic solvents as ethanol and ether, a normal solubility in glacial acetic acid, chloroform, and aqueous sodium hydroxide and it is almost insoluble in water [19]. On the other hand, the values of the solubility and $\mathrm{pH}$ of samples based on polyurethane structures with and without eugenol are presented in table 2 .

\begin{tabular}{|c|c|c|c|c|c|}
\hline \multirow{2}{*}{$\begin{array}{l}\text { Sample } \\
\text { code }\end{array}$} & \multicolumn{3}{|c|}{ Aqueous phase } & \multirow{2}{*}{$\begin{array}{c}\text { Organic phase } \\
\text { HMDI }\end{array}$} & \multirow{2}{*}{$\begin{array}{c}\text { Active substance } \\
\text { Eugenol }\end{array}$} \\
\hline & EG & PEG & Tween 20 & & \\
\hline EU_0 & $\mathrm{x}$ & $\mathrm{x}$ & $\mathrm{x}$ & $x$ & - \\
\hline EU_1 & $\mathrm{x}$ & $\mathrm{x}$ & $\mathrm{x}$ & $\mathrm{x}$ & $\mathrm{x}$ \\
\hline
\end{tabular}

Table 1

THE RECIPE OF THE SYNTHESIS 
Table 2

THE SOLUBILITY AND pH OF SAMPLES

\begin{tabular}{|l|r|r|}
\hline Parameter vs. Sample & \multicolumn{1}{|l|}{ EU_0 } & \multicolumn{1}{l|}{ EU_1 } \\
\hline $\mathrm{pH}$ & $6.71 \pm 0.11$ & $6.82 \pm 0.17$ \\
\hline Solubility in water, $\mathrm{mg} / \mathrm{mL}$ & 0.86 & 0.82 \\
\hline Solubility in ethanol, $\mathrm{mg} / \mathrm{mL}$ & 0.98 & 1.01 \\
\hline Solubility in acetone, $\mathrm{mg} / \mathrm{mL}$ & 1.10 & 1.11 \\
\hline Solubility in DMSO, $\mathrm{mg} / \mathrm{mL}$ & 1.07 & 1.09 \\
\hline
\end{tabular}

The DSCcurves of samples EU 0 and EU lindicate that were obtained very stable structures between -10 and $270^{\circ} \mathrm{C}$; it is known that polyurethane decomposition start at just $280^{\circ} \mathrm{C}$ [20]; on the other hand, the endothermic process of pure eugenol sample between 240 and $260^{\circ} \mathrm{C}$ can be associated with the boiling point of the active compound (in the scientific literature eugenol b.p.= $\left.254^{\circ} \mathrm{C}\right)$.

The size measurements of polyurethane structures with and withouteugenol were done using the same parameters of the instrument and the same concentration of samples. The results of structures' sizes are show $n$ in figure 3 and it can be observed that the average diameter of empty structures is $241 \mathrm{~nm}$, while the diameter of structures with eugenol is $289 \mathrm{~nm}$. This increase can be due to the fact that the active substance can play the role of a chain extender.

The particles' surface charge, analyzed by a Wallis Zetapotentialinstrument, depends on their electrophoretic mobility.

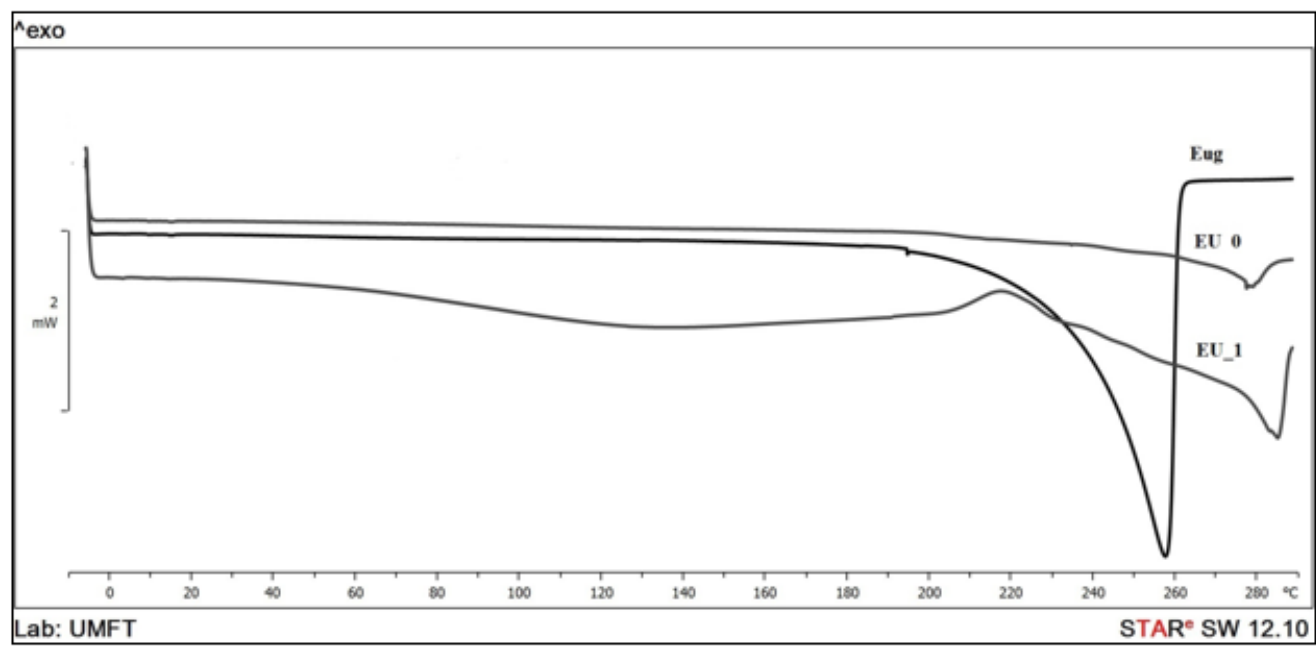

Fig. 2. DSC thermogramsofpure eugenol and obtained samples EU_0 and EU_1
No important differences between the mobility of samples EU_0 and EU_1 were obtained (fig. $4 a$ and b). The average resülts of samples are: the mobility $\mu_{\text {厂U }}=-4.85$ $\mu \mathrm{m} . \mathrm{cm} / \mathrm{V} . \mathrm{s}$ and Zeta potential $\xi_{\text {. }}=-62.33 \mathrm{mV}$, while the mobility $\mu_{\text {E }}=-4.34 \mu \mathrm{m} . \mathrm{cm} / \mathrm{V}$. s and Zeta potential $\xi_{\mathrm{EU}}=-55.76 \mathrm{mV}$. These results indicate thatboth samples present a very good stability against the tendency to form clusters; the literature indicate that the specific range of Zeta potential of colloidal structures unstable to agglomeration is between -30 and $+30 \mathrm{mV}$ [21].

The polyurethane structures present an UV-Vis maximum absorption around $300 \mathrm{~nm}$ with a small shift due to the addition of eugenol (fig. 5). Eugenol did not present a sharp peak, but its absorbance increase around 210 and $285 \mathrm{~nm}$. The first wavelength value was chosen to evaluate to quantity of free drug in order to establish the entrapment efficiency. There were used 5 standard solutions and the calibration curve. The results indicate an entrapment efficiency equal with $67 \%$.

Figure 6 present the evolution of some skin parameters often used in the prediction of new synthesized compounds' toxicity. It is known that an irritative compound will increase the transepidermal water loss and the erythema (redness of skin) and will decrease the level of stratum corneum hydration.

There are two main factors that are considered in all toxicological assays: (1) how the measured parameter is changed (if it increase / decrease / remain constant during the experiment)and (2) how much the measured parameter is changed (important or minimum change of values). In our experiment, all four skin parameters were modified: the transepidermal water loss, the melanin and erythema index increase; on the other hand, the hydration
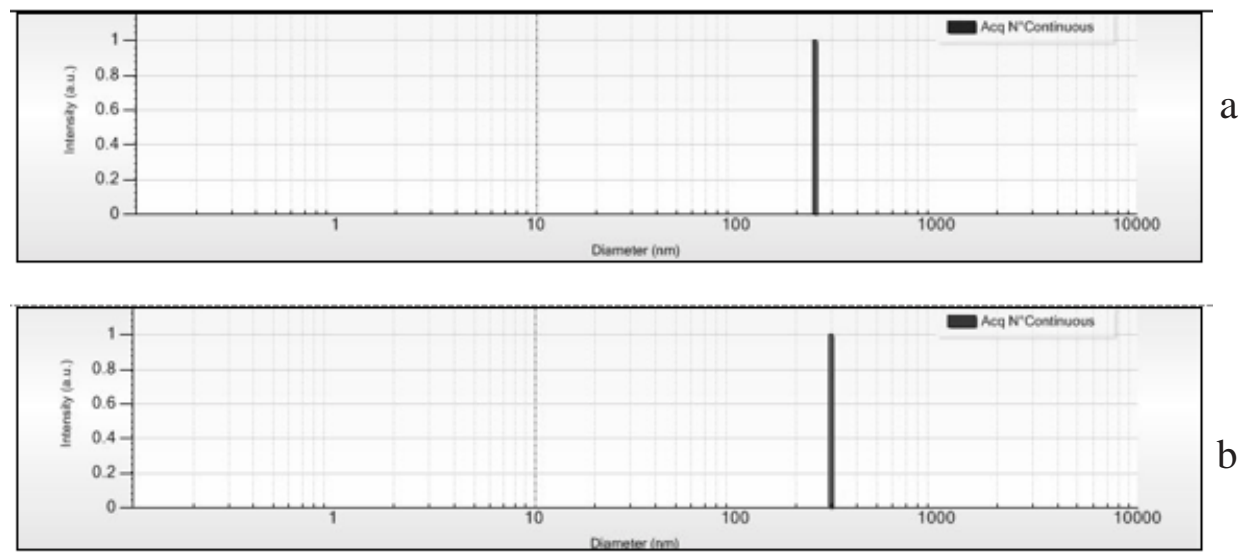

MATERIALE PLASTICE $\bullet 55$ No. $1 \bullet 2018$ 

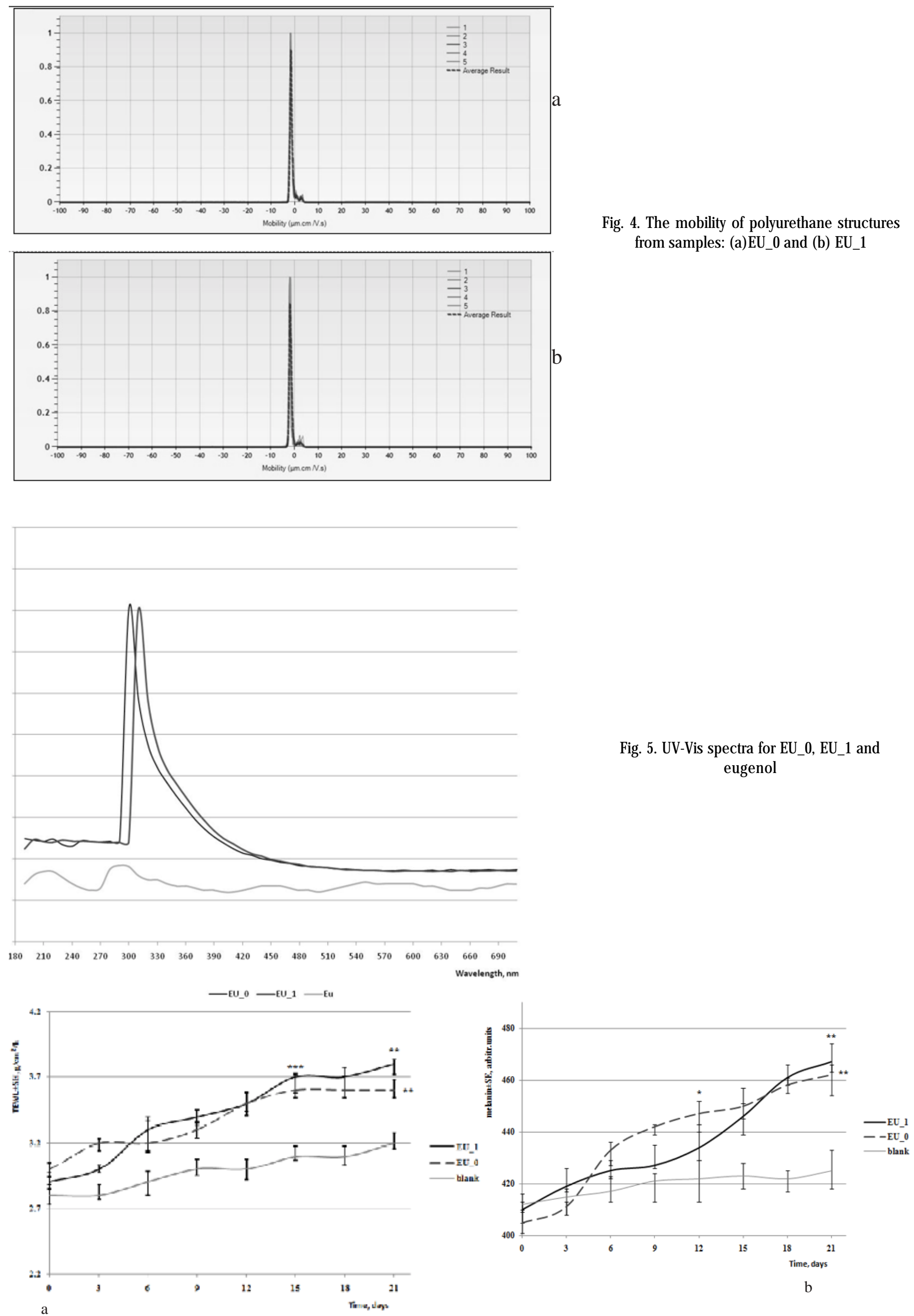

Fig. 6. The evolution of skin parameters: (a)TEWL, (b) melanin
Fig. 4. The mobility of polyurethane structures from samples: (a)EU_0 and (b) EU_1

Fig. 5. UV-Vis spectra for EU 0 , EU_ 1 and eugenol 

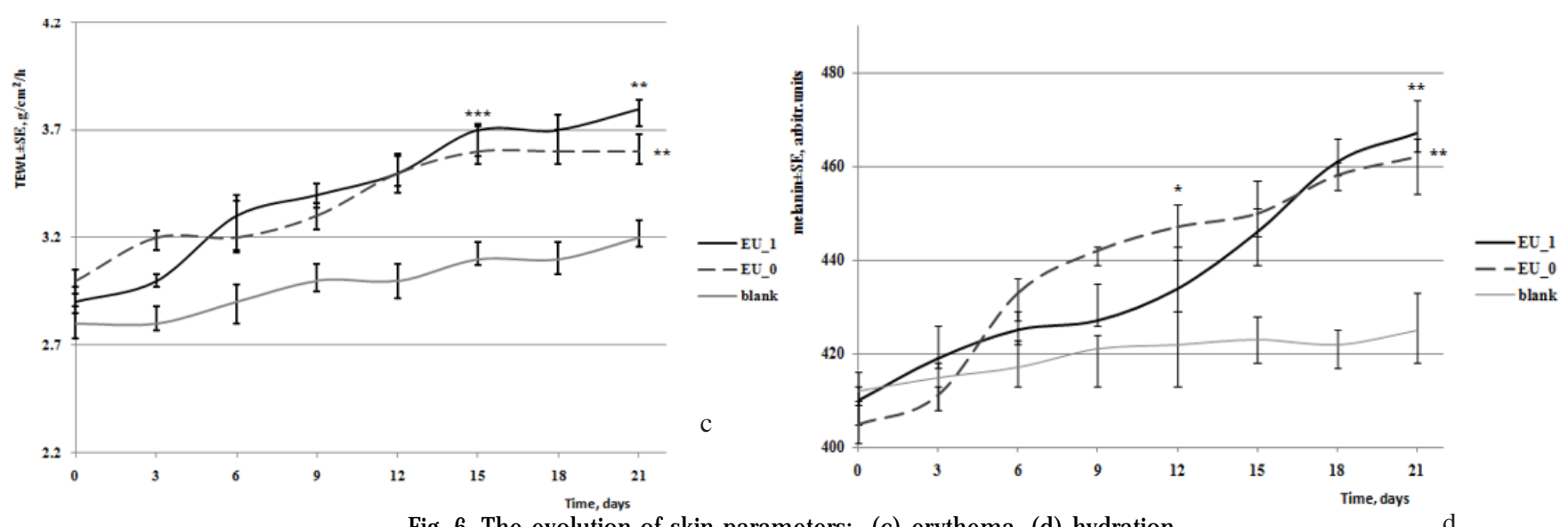

Fig. 6. The evolution of skin parameters: (c) erythema, (d) hydration

of stratum corneum decrease. So, the first factoris respected, and this is a condition for a positive test.

The changes of values are important and they are very different between the exposed samples and the blank in the case of toxic or irritative compounds. In our study, the modifications of skin parameters are not important (e.g.: the melanin scale is between 0-999 arbitrary units and we obtained changes just between 405 and 470, so the difference is $\Delta=65$ units related to a 1000 scale) and these modifications are comparable with those obtained for blank. This is the reason why, we consider that these samples do not present any toxic or irritative effect.

\section{Conclusions}

Polyurethane structures with and without eugenol were synthesized using a polyaddition process combined with a simultaneous emulsification. Structures with sizes between 241 and $289 \mathrm{~nm}$ were obtained, and they present a good thermal stability and an average $\mathrm{pH}$ of aqueous solution between 6.71 and 6.82 . The evaluation of encapsulation efficiency, based on UV-Vis absorption of free drug related to the quantity of eugenol added to synthesis, revealed a $67 \%$ of active agent entrapped inside the polyurethane structures. The bioevaluation of products, based on different assays on mice skin, suggest that these products are safe to use in oral therapies.

Acknowledgements: This work was financially supported byUEFISCDI (research contract PN-III-P2-2.1-BG-2016-0455) / 122BG and by Victor Babes University of Medicine and Pharmacy Timisoara, Romania (research contract no. 15250/2012) and Development of existing infrastructure and creation of newinfrastructure.POSCCE-A2- 02.2.12013- 1,Center of Genomic Medicine University of Medicine and Pharmacy Victor Babes Timisoara.

\section{References}

1. CINTA-PINZARU, S., DEHELEAN, C.A., SOICA, C., CULEA, M., BORCAN, F. Chem. Cent. J., 6, no. 1, 2012, p. 67.

2. HIGLEY, S.L. Hildegard of Bingen's Unknown Language: An Edition, Translation, and Discussion. New York: Palgrave Macmillian, 2007.

3. ROSE, J. The Aromatherapy Book: Applications and Inhalations. Barkeley: North Atlantic Books, 1992.
4. ZHOU, L., LIANG, D., HE, X., LI, J., TAN, H., LI, J., FU, Q., GU, Q. Biomater., 33, no. 9, 2012, p. 2734.

5. KUMBAR, S., LAURENCIN, C., DENG, M. Natural and Synthetic Biomedical Polymers. Amsterdam: Elsevier Inc., 2014.

6. DAVIM, J.P. The design and manufacture of medical devices.Sawston: Woodhead Publishing Ltd., 2012.

7. BORCAN, F., SOICA, C.M., GANTA, S., AMIJI, M.M., DEHELEAN, C.A., MUNTEANU, M.F. Chem. Cent. J., 6, no. 87, 2012, p. 1.

8. BORCAN, F., SOICA, C.M., DEHELEAN, C.A., GANTA, S., AMIJI, M.M. Rev. Chim. (Bucharest), 63, no. 11, 2012, p. 1164.

9. HEGHES, A., SOICA, C.M., ARDELEAN, S., AMBRUS, R., MUNTEAN, D., GALUSCAN, A., DRAGOS, D., IONESCU, D., BORCAN, F. Chem. Cent. J., 7, no. 66, 2013, p. 1.

10. GALUSCAN, A., JUMANCA, D., BORCAN, F., SOICA, C.M., IONESCU, D., RUSU, L.C., CRAINICEANU, Z. Rev. Chim. (Bucharest), 65, no. 2, 2014, p. 190.

11. JUMANCA, D., GALUSCAN, A., PODARIU, A.C., BORCAN, F., EARAR, K. Rev. Chim. (Bucharest), 65, no. 12, 2014, p. 1473.

12.CITU, I.M., TOMA, C., TRANDAFIRESCU, C., ANTAL, D., ZAMBORI, C., OPREAN, C., BOJIN, F., BORCAN, F., PAUNESCU, V., LAZUREANU, V. Rev. Chim. (Bucharest), 66, no. 3, 2015, p. 431.

13. CITU, C., CEUTA, L., POPOVICI, R., IONESCU, D., PINZARU, I., BORCAN, F. Mat. Plast,,52, no. 4, 2015, p. 553.

14. TRANDAFIRESCU, C., LEDETI, I., CORICOVAC, D.E., SOICA, C.M., PINZARU, I., DEHELEAN, C.A., IACOB, R.E., BORCAN, F. Mat. Plast.,53, no. 2, 2016, p. 205.

15.OPREAN, C., BORCAN, F., PAVEL, I., DEMA, A., DANCIU, C., SOICA, C., DEHELEAN, C., NICU, A., ARDELEAN, A., CRISTEA, M., IVAN, A., TATU, C., BOJ IN,F. In Vivo, 30, no. 5, 2016, p. 633.

16. MUNTEANU, M.F., ARDELEAN, A., BORCAN, F., TRIFUNSCHI, S.I., GLIGOR, R., ARDELEAN, S.A., CORICOVAC, D., PINZARU, I., ANDRICA, F., BORCAN, L-C. Curr.Drug Delivery, 14, 2017(E-pub Ahead of Print). 17.MOLERIU,L., DUSE,A.O., BORCAN,F., SOICA,C., KURUNCZI,L., NICOLOV,M., MIOC,M. Mat. Plast,,54, no. 2, 2017, p.348.

18.DORA, CP, SINGH, S.K., KUMAR, S., DATUSALIA,A.K., DEEP, A. ActaPoloniae Pharm. Drug Res., 67,no. 3, 2010, p. 283.

19.*** Eugenol CAS 97-53-0. Technical information. Available at: www.scbt.com (Lastaccessed July $3^{\text {rd }}$, 2017).

20. BOLCU, C., BORCAN, F., DUDA-SEIMAN, C., NUTIU, R. Mat.Plast.,46, no. 3, 2009, p. 315.

21. SALOPEK, B., KRASI, D., FILIPOVIC, S. Rudarsko-geoloikonaftnizbornik, 4, 1992, p. 147

Manuscript received: 7.10 .2017 